\title{
Standar Operasional Prosedur (SOP) Izin Investasi Dalam Meningkatkan Minat Investor di Kota Depok
}

\author{
Siti Nurchalizah ${ }^{1}$, dan Sri Ernawati ${ }^{2}$ \\ Sekolah Tinggi Ilmu Ekonomi (STIE) Bima \\ Email Address: \\ sitinurchalizah17.stiebima@gmail.com \\ sriernawati.stiebima@gmail.com
}

\begin{abstract}
The research data processed is from the results of in-depth interviews or indepth interviews for informants. The data sample was taken by snowball sampling. Data processing and analysis using SWOT. From the results of data processing, it was found that the internal and external matrices were compiled from the total score of the IFE (internal factor evaluation) and EFE (external factor evaluation) matrices which were valued (2.955 and 3.08). This can show that the position of the Standard Operating Procedure for investment permit procedures in increasing investor interest in the Depok City - West Java Investment and One Stop Integrated Services Service is in square II, which is this position shows that the Standard Operating Procedure for investment permits in increasing investor interest in the Department. Investment and One Stop Integrated Services for Depok City - West Java is growing and developing.
\end{abstract}

Key words: Standard Operating Procedures, Investment Permit,Investor Interest.

\begin{abstract}
Abstrak: Data penelitian yang diolah adalah dari hasil wawancara mendalam atau in depth interview untuk para informan. Sampel data diambil secara snowball sampling. Olah data dan analisis dengan menggunakanSwot. Dari hasil olah data ditemukan bahwa Dari Matrik internal dan eksternal disusun dari total skor matrik IFE (internal factor evaluation) dan EFE (eksternal factor evaluation) yang bernilai (2,955 dan 3,08). Hal ini dapat menunjukan bahwa posisi Standar Operasional Prosedur izin investasi dalam meningkatkan minat investor pada Dinas Penanaman Modal Dan Pelayanan Terpadu Satu Pintu Kota Depok - Jawa Barat berada pada kuadrat II yaitu posisi ini menunjukan bahwa Standar Operasional Prosedur izin investasi dalam dalam meningkatkan minat investor pada Dinas Penanaman Modal Dan Pelayanan Terpadu Satu Pintu Kota Depok - Jawa Barat adalah tumbuh dan kembangkan.
\end{abstract}

Kata Kunci:Standar Operasional Prosedur, Izin Investasi, Minat Investor.

\section{PENDAHULUAN}

Sekarang ini kegiatan penanaman modal atau yang lebih dikenal sebagai investasi sangat menaruh kontribusi yang relatif signifikan dalam pertumbuhan perekonomian Indonesia. Baik investasi yang ada di Indonesia ataupun yang ada di luar negeri. 
Mengingat pentingnya aktivitas investasi tersebut, pemerintah menghimbau para investor asing dan investor lokal buat menanamkan modalnya pada Indonesia. Sebagai upaya buat mengembangan perekonomian Indonesia sangat diperlukannya kiprah investor yg mana Penelitian mengenai peningkatan minat berinvestasi pada pasar modal syariah sudah ditelaah Bapepam LK pada tahun 2011 yang mana faktor yang mempengaruhi minat berinvestasi dikelompokkan sebagai 2 faktor yaitu internal \& eksternal. (Malik, 2017)

Izin investasi merupakan payung hukum bagi pemerintah untuk melindungi kegiatan investasi baik bagi investor maupun bagi negara. Ada beberapa permasalahan yang menjadi terkendalanya proses pelayanan publik pelayanan perizinan termasuk Investasi yang dapat mempengaruhi iklim usaha yaitu pertama, Faktor Prosedur perizinan usaha yang panjang dan membutuhkan banyak biaya. Kedua, faktor rendahnya kepastian hokum. Ketiga, faktor dari kualitas Sumber Daya Manusia dan terbatasnya infrastruktur, kurang bergairahnya iklim usaha di bidang investasi disebabkan oleh keterbatasan daya saing produksi dan kapasitas dari sistem dan jaringan infra struktur yang sebagaian besar dalam keadaan rusak akibat krisis (Widyastuti, 2014). Hampir semua organisasi di Indonesia bahkan dunia memiliki prosedur operasi standar (SOP). Tidak hanya di pemerintahan, pendidikan dan bidang lainnya. Diperlukan suatu sistem atau standar untuk semua operasi perusahaan di setiap bidang untuk mengetahui apakah produk perusahaan memenuhi standar yang ada dan untuk memeriksa kinerja karyawan perusahaan (Gabriele, 2018). SOP adalah serangkaian catatan yang jelas, pedoman lengkap dan rinci tentang proses, tugas dan peran masing-masing individu atau kelompok yang dijalankan sehari-hari dalam organisasi. Secara fungsional, fungsi SOP adalah membentuk sistem dan alur kerja yang tertib, sistematis, dan bertanggung jawab, serta menjelaskan bagaimana melaksanakan tujuan kerja sesuai dengan kebijakan dan peraturan yang berlaku (Rachmi et al., 2014).

Masyarakat yang memenuhi kebutuhan dasar akan meningkatkan kegiatan investasi ekonominya. Jenis investasi tersebut antara lain tabungan, emas, tanah, surat berharga (saham dan obligasi) dan lain-lain. Investasi seharusnya tidak digunakan sekarang, tetapi investasi harus digunakan di masa depan. Investasi dapat dijelaskan sebagai penundaan konsumsi, yang kini telah digunakan untuk produksi efektif dalam jangka waktu tertentu (Bahri, 2018). Menurut teori perilaku terencana, salah satu aspek yang dapat mempengaruhi minat adalah pengendalian perilaku yang dipersepsikan. Kontrol perilaku yang dirasakan didasarkan pada keyakinan individu apakah ada aspek yang mendukung atau hambatan untuk berperilaku (Sriasih dan Wahyuni, 2020). Preferensi investasi memiliki alasan berbeda untuk menentukan pilihan investasi. Faktor terpenting untuk dipertimbangkan adalah tingkat risiko dan pengembalian. Tren yang muncul adalah keinginan masyarakat untuk memperoleh resiko tinggi tetapi resiko rendah. Semakin tinggi risikonya, semakin tinggi keuntungannya. akan. (Tandio dan yang lainnyaBeberapa orang berinvestasi karena berbagai alasan, antara lain untuk memenuhi kebutuhan likuiditasnya, menabung untuk menambah keuntungan, berencana pensiun bahkan berspekulasi (Nurlita, 2014). Beberapa peneliti sebelumnya mempelajari izin investasi dan menganalisis minat investor dalam berinvestasi. Penelitian peneliti sebelumnya (Aminudin, 2017) menegaskan bahwa sesuai dengan peraturan perundang-undangan yang berlaku, peningkatan investasi di bidang wisata trampolin efektif dan efisien. Tanggung jawab dan fungsi tersebut dijalankan sesuai dengan standar operasional prosedur (SOP) 
yang digunakan di BPM dan kemudian diteliti (Gunawan et al., 2020). Laporan tersebut menunjukkan bahwa Indeks Kepuasan Komunitas (ICM) tidak puas dengan produktivitas masyarakat dan kepuasan layanan lisensi (2.77), dan proses analisis jaringan kebijakan (ANP) tidak memuaskan. 84), meningkatkan kualitas dan kuantitas sumber daya manusia $(0,277)$. , Anggaran tambahan $(0,241)$, definisi kelompok teknologi atap $(0,186)$, dan minat investasi penelitian (Pristivo, 2016) Hal ini menunjukkan bahwa sebagian besar investor di Kota Serang tertarik untuk berinvestasi dalam hukum Syariah di pasar modal syariah, dan penelitian (Tumewa, 2019) menunjukkan bahwa jumlah anak muda yang tertarik untuk menggunakan teknologi fintech dan berinvestasi di ibu kota telah meningkat. pasar dikonfirmasi oleh penelitian (Hati \& Herefa, 2020), yang menunjukkan bahwa motivasi, pengetahuan pasar modal dan risk appetite berlaku untuk manfaat investasi kaum milenial.

Badan Koordinasi Penanaman Modal (BKPM) memperkenalkan sistem Pelayanan Terpadu Satu Pintu (PTSP) yang mengintegrasikan proses implementasi ke dalam proses dari tahap aplikasi hingga penyelesaian proses door-to-door, dan memberi investor beberapa opsi manajemen di proses persetujuan investasi Kantor pelayanan. Kota terpadu Depok-Jawa Barat. Standar Operasional Standar (SOP) ini harus sesuai dengan pedoman dan prosedur penerapan investasi yang diatur dalam Peraturan Nomor 12 Tahun 2009 (Perka BKPM12 / 2009) agar tercapai konsistensi dan kelancaran penyelesaian proses konsultasi dan penyediaan jasa penanaman modal.Bagi investor, ini sederhana, cepat, akurat dan transparan. Prosedur operasi standar (SOP) persetujuan investasi di Kota Depok dan Kantor Pelayanan Terpadu Satu Pintu sangat baik. Pasalnya, organisasi investasi dan pelayanan terpadu Kota Depok telah menerapkan sistem perizinan online khusus untuk perizinan perusahaan. Si-MPOK, sistem ini merupakan aplikasi yang dapat diluncurkan di Kota Depok pada tahun 2018 untuk memberikan layanan perizinan dan nonperizinan secara online.Dinas Pelayanan Terpadu dan Pelayanan Penanaman Modal Kota Depok melanggar izin Presiden Republik Indonesia Nomor 97 Tahun 2014 tentang Penyelenggaraan Pelayanan Terpadu Satu Jendela. Pasal 17 mengatur bahwa izin penyelenggaraan pelayanan terpadu bukan lisensi satu atap harus digunakan Departemen Investasi Layanan Elektronik (PSE) dan layanan terpadu satu pintu Kota Depok - Jawa Barat. 


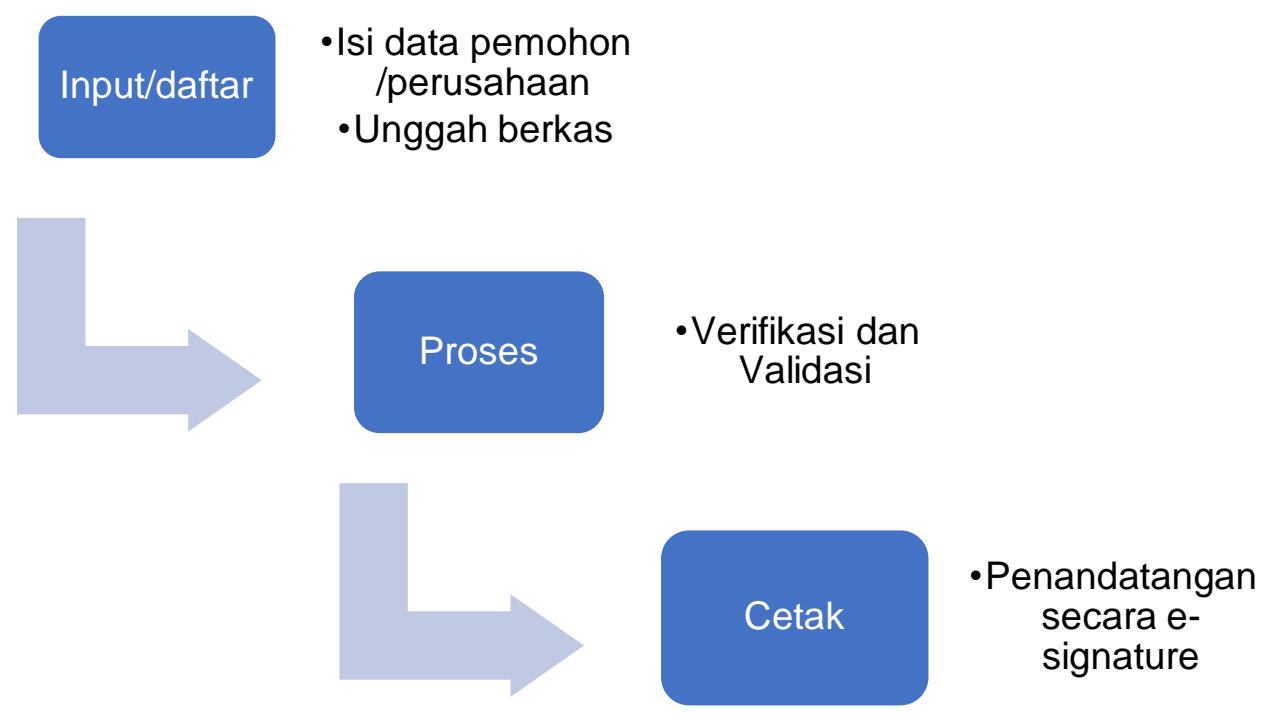

Gambar 1. Model Penelitian

Untuk itu, Kantor Dinas Penanaman Modal Dan Pelayanan Terpadu Satu Pintu (DPMPTSP) dan Pelayanan Terpadu Satu Pintu menjadi penyelenggara PTSP yang memberikan layanan kepada investor untuk mendapatkan izin penanaman modal di Kota Depok - Jawa Barat. Kantor Dinas Penanaman Modal Dan Pelayanan Terpadu Satu Pintu Kota Depok - Jawa Barat akan terus bekerja keras untuk meningkatkan standar operasional prosedur (SOP) dan meningkatkan kenyamanan. Sebagai bagian dari layanan investor, baru-baru ini diverifikasi bahwa Depok City Investment dan organisasi layanan terpadu satu atap telah memperoleh sistem manajemen mutu Organisasi Internasional untuk Standardisasi (ISO) 9001: 2015 (sertifikasi QMS). Dari PT. Sertifikasi Tirt Mourney. ISO 9001: 2008 adalah standar internasional yang mengatur sistem manajemen mutu layanan. Kualitas produk tidak hanya bergantung pada layanan, tetapi juga pada persyaratan lain, seperti layanan tepat waktu dan pembiayaan. Kepuasan investor dan dukungan regulasi yang ada, termasuk standar operasi. Prosedur (SOP). Tujuannya adalah untukMeningkatkan minat investor untuk meningkatkan tingkat investasi Kota Depok Jawa Barat. 


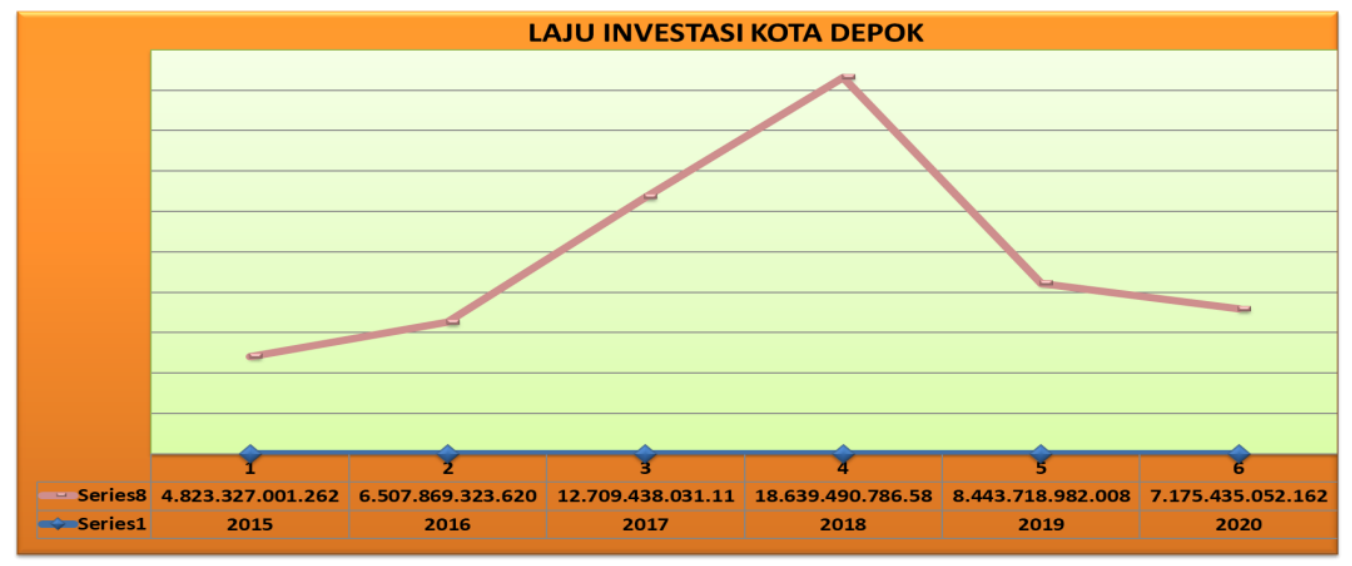

Gambar 2. Grafil Investasi

Dengan semakin besarnya minat investor untuk menanamkan modalnya di Kota Depok (termasuk penyediaan layanan publik), pemerintah berkomitmen kepada seluruh warga dan masyarakat. Oleh karena itu, metode dan prosedur harus selalu diperbarui sesuai dengan harapan dan keinginan pemerintah dan masyarakat.

\section{KAJIAN TEORI}

Standar Operasional Prosedur (SOP), Perusahaan telah menyusun standar operasional prosedur (SOP) sebagai acuan oleh karyawan, sehingga manajer dan karyawan dapat menjadi sumber daya perusahaan yang profesional dan dapat diandalkan. Standar Operasional Prosedur (SOP) menjelaskan peran dan tanggung jawab masing-masing karyawan, seperti: B. Siapa penanggung jawab dan penanggung jawab, kapan harus menyelesaikan, kapan harus melakukan proses kerja, dokumen apa yang dibutuhkan dan siapa menyetujui (Setiawati, 2015). Prosedur operasi standar (SOP) adalah dokumen tertulis yang meliputi:1) Alur kerja, 2) Langkah-langkah sistem dan 3) Serangkaian instruksi untuk kegiatan rutin dan berulang yang harus diikuti organisasi (Ramadhan, Syaharudin, Prajitiasari 2015). Standard Operating Procedure hal ini dimaknai sebagai proses non klinis yang dilakukan secara terencana, seperti penyediaan alat bantu secara terus menerus seperti obat-obatan, alat kesehatan, dan lain-lain (Bustami 2011).

Izin Investasi. (Syahyunan, 2015) izin investasi adalah komitmen investasi yang bertujuan untuk menarik banyak dana atau sumber daya lain yang sedang berjalan untuk menghasilkan keuntungan di masa depan. Investor membeli sejumlah saham hari ini untuk mendapatkan keuntungan dari kenaikan harga saham atau kenaikan dividen sebagai keuntungan di masa depan. Waktu dan risiko terkait dengan investasi. Selain itu (Hartono, 2017), investasi mengacu pada pengalihan konsumsi saat ini yang termasuk dalam kekayaan produktif selama suatu periode waktu.(Lubis, 2016) Membuat keputusan investasi sangat bergantung pada informasi yang diterima dan pemahaman investor tentang investasi. Setiap investor memiliki keterampilan dan pengetahuan yang berbeda (Putra et al., 2016). Posisi investor dalam pengambilan keputusan investasi ada dua yaitu 
sikap rasional dan irasional. Nalar adalah sikap yang masuk akal, sedangkan irasional adalah sikap yang tidak masuk akal InvestorDengan menggunakan pendekatan rasional, Anda akan membuat keputusan berdasarkan pengetahuan keuangan.

Minat Investor. (Syahunan, 2015) Tujuan investor ketika berinvestasi adalah untuk mendapatkan keuntungan. Investasi yang dilakukan oleh investor merupakan salah satu alternatif investasi yang diharapkan dapat menghasilkan return tertinggi. Namun pada kenyataannya return aktual (actual return) yang sebenarnya diterima investor tidak selalu sama dengan ekspektasi return sebelumnya (expected return). Dengan kata lain, investor yang berinvestasi cenderung lebih untung. risikoPenyimpangan pendapatan aktual dari tingkat keuntungan yang diharapkan. Manfaat dari (Ferdinant, 2016) dapat ditentukan dengan menggunakan indikator-indikator sebagai berikut: 1. Manfaat transaksi yaitu kecenderungan investasi; 2. Manfaat referensi yaitu kecenderungan seseorang untuk mengarahkan investasi kepada orang lain; 3. Manfaat prioritas. Jelaskan minat pada perilaku manusia,Preferensi investasi utama. 4. Minat penelitian. Minat ini menggambarkan perilaku seseorang yang selalu mencari informasi tentang investasi yang diminatinya dan informasi yang menegaskan karakteristik positif dari investasi tersebut.

\section{METODELOGI}

Populasi dan Teknik Pemilihan Sampel. Populasi dalam penelitian ini adalah seluruh pegawai Dinas Penanaman Modal Dan Pelayanan Terpadu Satu Pintu Kota Depok - Jawa Barat yang berjumlah 97 orang pegawai dan seluruh investor yang berinvestasi di Kota Depok - Jawa Barat yang berjumlah 673 orang investor. Responden dalam penelitian ini adalah pegawai Dinas Penanaman Modal Dan Pelayanan Terpadu Satu Pintu Kota Depok - Jawa Barat yang berjumlah 3 orang dan investor yang mengurus izin investasi dan yang sudah berinvestasi di Kota Depok - Jawa Barat yang berjumlah 12 orang investor.

Informan ialah orang yang terbiasa memberikan informasi tentang situasi dan kondisi suatu penyelidikan. Anda harus memiliki pengalaman penelitian yang luas (Moleong, 2016). Oleh karena itu, informan harus benar-benar mengenal partisipan yang terkait langsung dengan tujuan penelitian. Pilihan penyedia informasi harus didasarkan pada kemampuan mereka, bukan hanya pernyataan mereka.

Kumpulkan informasi tentang subjek penelitian berdasarkan fenomena yang diamati. Pemilihan didasarkan pada pemahaman responden terhadap fenomena penelitian. Informasi lain diperoleh dari informan lain yang menggunakan metode snowball sampling untuk mengidentifikasi. Kecuali jika ada informasi lain yang tersedia atau ada kendala keuangan dan waktu, pencarian pelapor akan dihentikan. Berikut ini informan-informan yang menjadi sumber data dalam penelitian ini adalah: (1) Pegawai Dinas Penanaman Modal Dan Pelayanan Terpadu Satu Pintu (DPMPTSP) Kota Depok - Jawa Barat Dalam Hal ini yang dipilih yaitu kasi Perencanaan Pengembangan Promosi dan Kerjasama Penanaman Modal (P3KPM) pada Bidang Penanaman Modal karena dianggap mampu menjawab permasalahan yang sedang diteliti yang terkait dengan Standar Operasional Prosedur (SOP) izin investasi dalam meningkatkan minat investor pada Dinas Penanaman Modal Dan Pelayanan Terpadu Satu Pintu (DPMPTSP) Kota Depok - Jawa Barat. (2) 
Investor yang terdiri dari investor yang baru melakukan investasi dan sudah lama melakukan investasi dengan kisaran waktu 5 Tahun.

Dalam penelitian ini subjek penelitian disebut partisipan, hubungan antara peneliti dengan partisipan harus dijaga agar penelitain bisa lancar dan hasilnya bisa akurat, untuk itu harus ada etika dalam penelitian agar pihak peneliti dan informan bisa saling berkerja sama dengan baik.

Penelitian dilakukan setelah mendapatkan judul penelitian dan izin untuk melakukan penelitian pada Dinas Penanaman Modal Dan Pelayanan Terpadu Satu Pintu (DPMPTSP) Kota Depok - Jawa Barat. Peneliti melakukan wawancara dengan menekankan pada etika meliputi (Neni, 2011): (1) Informed consent (lembar persetujuan menjadi partisipan). Sebelum lembar persetujuan diberikan untuk partisipan, maka sebelum itu peneliti menjelaskan maksud, tujuan, keuntungan, dan kerugian penelitian yang nanti akan dilakukan kepada partisipan. (2) Anonimity (tanpa nama). Dalam menjaga kerahasiaan partisipan, maka peneliti tidak mencantumkan nama terang partisipan, tapi peneliti hanya menggunakan inisial atau simbol berupa sebutan partisipan seperti P.2, P.2, I.1, I.2, I.3. (3) Confidentiality (kerahasiaan). Kerahasiaan data-data yang diterima dari responden akan dijamin oleh peneliti. Bila ada forum khusus maka peneliti akan memberikan data-data yang telah didapatkan dari wawancara tanpa memberi nama asli partisipan. (4) Right to withdraw. Partisipan berhak untuk mengundurkan diri sebagai partisipan, jika partisipan menolak untuk diteliti maka peneliti tidak akan memaksa dan tetap menghormati keputusan partisipan. (5) Protection from discomfort. Partisipan berhak mendapat perlindungan dari berbagai ketidaknyamanan yang mungkin akan muncul selama proses wawancara. Seperti partisipan sudah lelah sehingga yang dilakukan oleh peneliti ialah menghentikan proses wawancara dan akan dilanjutkan lagi sesuai waktu yang sudah disepakati oleh partisipan dan peneliti sebelum proses wawancara selesai.

Teknik Pengumpulan Data. Wawancara mendalam atau in depthinterview, Peneliti melakukan pertemuan secara langsung dengan informan dengan mengajukan berbagai pertanyaan yang sudah disusun terleih dahulu. Pada proses wawancara yang dilakukan ini di dokumentasi dalam bentuk catatan tertulis dan Audio Visual, hal ini di gunakan untuk meningkatkan nilai dari data yang akan diperoleh. Rencana awal wawancara yang dilakukan secara lisan dan tatap muka dengan 10 (sepuluh) partisipan yang dianggap memiliki karakteristik yang dapat membantu peneliti dalam pengambilan kesimpulan dalam penelitian ini yaitu 3 (tiga) orang pegawai Dinas Penanaman Modal Dan Pelayanan Terpadu Satu Pintu (DPMPTSP) Kota Depok - Jawa Barat. 1 (satu) orang investor melakukan investasi di Kota Depok, jumlah ini akan berubah sesuai dengan kebutuhan data dilapangan. Proses wawancara yang dilakukan ialah dengan mengajukan beberapa pertanyaan yang telah disusun terlebih dahulu sesuai dengan kapasitas masing-masing partisipan dengan alokasi waktu kurang lebih 1 (satu) jam dan pemilihan tempat sesuai dengan kesepakatan antara peneliti dan partisipan.

Obsevasi. Peneliti melakukan pengamatan langsung tentang apa saja yang dilakukan oleh pegawai dan investor. 
Dokumentasi. Penelitian meminta data tentang SOP, perkembanagn investasi untuk menunjang data penelitian.

\section{HASIL DAN PEMBAHASAN}

\section{Standar Operasional Prosedur (SOP)}

Prosedur Kerja. Berikut ini beberapa pernyataan informan terkait dengan prosedur kerja yaitu: Prosedur kerja pada Dinas Penanaman Modal Dan Pelayanan Terpadu Satu Pintu (DPMPTSP) Kota Depok - Jawa Barat mempunyai tugas untuk merumuskan dan melaksanakan kebijakan pada bidang penanaman modal dan penyelenggaraan pelayanan administrasi penanaman modal, perizinan dan non perizinan secara terpadu dengan prinsip koordinasi, integrasi, sinkronisasi, simplifikasi, keamanan, kepastian dan transparansi. (P.2).

Prosedur kerja untuk melakukan investasi di kota depok ialah dengan mendirikan usaha dan melakukan pendaftaran, memperoleh perizinan persiapan dan kontruksi, memperoleh perizinan untuk pelaksanaan dan operasional, penggunaan tenaga kerja asing, serta mendapatkan fasilitas penanaman modal. (P.3).

Tahapan Yang Sistematis. Berikut ini beberapa pernyataan informan terkait dengan tahapan yang sistematis yaitu: Investor yang akan berinvestasi di Kota Depok harus melalui beberapa tahapan yang sistematis dan sesuai dengan peraturan perundanganundangan yang berlaku di Indonesia. (P.1).

Tahapan dalam melakukan izin investasi harus sesuai dengan tahapan yang sistematis agar proses perizinan investasi akan diperlukan oleh investor semakin mudah dan cepat. Dengan kemudahan tersebut, diharapkan investasi di Kota Depok akan semakin meningkat. (P.3).

Aktivitas. Berikut ini beberapa pernyataan informan terkait dengan aktivitas yaitu: Dinas Penanaman Modal Dan Pelayanan Terpadu Satu Pintu Kota Depok tetap melakukan aktivitas pelayanan prima di tengah pandemi covid-19 hingga saat ini telah di terapkan pemberlakuan pembatasan kegiatan masyarakat. Upaya mempermudah pelayanan di masa pandemi covid-19 terus dilakukan dengan memberlakukan jam pelayanan sementara yaitu dari pukul $08.00-11.30$ WIB. (P.2)

Dinas Penanaman Modal Dan Pelayanan Terpadu Satu Pintu Kota Depok berencana membangun Mall Pelayanan Publik (MPP) pada tahun 2021 ini, dengan tujuan untuk lebih mempermudah proses pelayanan khususnya pelayanan perizinan investasi yang bertujuan untuk meningkatkan laju investasi di Kota Depok. (P.3)

Izin Investasi. Berikut ini beberapa pernyataan informan terkait dengan izin investasi yaitu: Eksistensi Dinas Penanaman Modal Dan Pelayanan Terpadu Satu Pintu Kota Depok sebagai instansi pelayanan perizinan semakin diakui oleh masyarakat dan para investor.Dengan inovasi yang terus dilakukan seperti penataan ruang pelayanan, penguatan regulasi, dan kelembagaan, penggunaan aplikasi Si-MPOK, semakin 
memperkuat komitmen mewujudkan pelayanan publik yang cepat, mudah dan transparan. (P.1).

Dinas Penanaman Modal Dan Pelayanan Terpadu Satu Pintu Kota Depok tidak hanya berfungsi untuk meningkatkan jumlah investasi yang lebih besar dari dalam maupun luar negeri, namun juga meningkatkan pelayanan perizinan investasi dan pelayanan perizinan dan non perizinan yang prima sebagaimana yang tertuang dalam keputusan Menpan Nomor 81 Tahun 1993, antara lain: sederhana, jelas, aman, transparan, efisien, adil dan tepat waktu. (P.2).

\section{Minat Investor}

Minat transaksional. Berikut ini beberapa pernyataan informan terkait dengan minat transaksional yaitu: Kami sangat memahami proses dan alur perizinan investasi pada Dinas Penanaman Modal Dan Pelayanan Terpadu Satu Pintu Kota Depok karena kami telah melakukan perizinan investasi lebih dari satu kali. Disamping proses pengurusan izin investasinya pun sangat mudah sehingga kami telah mengetahui Standar Operasional Prosedur izin investasinya secara detail dan lebih mendalam. Ini yang membuat kami ingin terus berinvestasi di Kota Depok. (I.8).

Sejauh ini tidak ada kelemahan dari Standar Operasional Prosedur izin investasi terhadap investasi maupun terhadap perkembangan investasi kami.Hal ini yang membuat kami terus ingin berinvestasi di Kota Depok. (I.9).

Minat referensial. Berikut ini beberapa pernyataan informan terkait dengan minat referensial yaitu: Standar Operasional Prosedur izin investasi pada Dinas Penanaman Modal Dan Pelayanan Terpadu Satu Pintu Kota Depok sudah sangat baik dan cukup standar baik dari sisi kelengkapan informasi, alur, bahkan administrasi serta prosesnya.Hal ini yang membuat kami tertarik untuk berinvestasi dan selalu mengajak rekan-rekan kami untuk melakukan investasi di Kota Depok. (I.1).

Standar Operasional Prosedur izin investasi sangat memberikan pengaruh terhadap perkembangan investasi kami. Karena dengan Standar Operasional Prosedur izin investasi yang mudah dan transparan kami dapat mengembangkan investasi kami, bahkan menambahkan investasi pada bidang yang lain. Ini salah satu alasan kenapa kami selalu exited mengajak sanak saudara dan rekan-rekan kami jika ingin memulai investasi sebaiknya dilakukan di Kota Depok saja. (I.4).

Minat preferensial. Berikut ini beberapa pernyataan informan terkait dengan minat preferensial yaitu: Standar Operasional Prosedur ijin investasi kami jadikan sebagai tolak ukur dan standar bagi kami untuk melakukan kegiatan investasi selanjutnya, jika Standar Operasional Prosedur izin investasinya sudah memiliki standar yang jelas, transparan, terukur dan prosesnya mudah serta tidak berbelit maka bisa menjadi pertimbangan bagi kami untuk melakukan kegiatan investasi berikutnya karena jika Standar Operasional Prosedur izin investasi bagus maka akan berdampak pada perkembangan investasi kedepannya. Hal ini yang selalu membuat kami memprioritaskan Kota Depok sebagai daerah untuk berinvestasi. (I.11). 
Sejauh ini Standar Operasional Prosedur izin investasi tidak memberikan ancaman apapun bagi kami, justru kami merasa bahwa Standar Operasional Prosedur izin investasi memberikan peluang bagi investasi kami karena kemudahan, transparansi serta informasiinformasi yang mudah untuk di dapat. Bukan hanya itu letak Kota Depok yang strategis karena berdekatan dengan Ibukota DKI Jakarta, akses transportasi, infrastruktur, dan demografi merupakan faktor yang dapat meningkatkan investasi kami. Itu yang menjadi alasan kami untuk selalu mengutamakan Kota Depok sebagai daerah untuk berinvestasi. (I.10).

Minat eksploratif. Berikut ini beberapa pernyataan informan terkait dengan minat eksploratif yaitu: Informasi Standar Operasional Prosedur izin investasi pada Dinas Penanaman Modal Dan Pelayanan Terpadu Satu Pintu Kota Depok - Provinsi Jawa Barat sudah sangat meluas karena sering dilakukan sosialisasi oleh Pemkot Depok khususnya Dinas Penanaman Modal Dan Pelayanan Terpadu Satu Pintu melalui Pemerintah Kelurahan, website DinasPenanaman Modal Dan Pelayanan Terpadu Satu Pintu serta media online serta media cetak milik pemerintah Kota Depok sehingga diketahui oleh seluruh lapisan masyarakat serta kami para pengusaha dan investor yang ada di Kota Depok maupun diluar Kota Depok.Sehingga informasi yang kami butuhkan sudah sangat lengkap kami dapatkan. (I.12).

Informasi yang kami butuhkan tentang izin investasi yang ada di Kota Depok sudah kami dapatkan dari sosialisasi yang dilakukan oleh Pemerintah Kota Depok khususnya Dinas Penanaman Modal Dan Pelayanan Terpadu Satu Pintu melalui pemerintah kelurahan, webside DPMPTSP, serta melalui media online dan media cetak. Sehingga kami sudah sangat mengetahui informasi terkait Standar Operasional Prosedur (SOP) izin investasi. (I.5).

Analisis Matrik IFE. Untuk melihat bagaimana analisis Standar Operasinal Prosedur izin investasi dalam meningkatkan minat investor pada Dinas Penanaman Modal Dan Pelayanan Terpadu Satu Pintu (DPMPTSP) Kota Depok - Jawa Barat dilihat pada faktor Internal. Bisa dilihat pada matrik IFE dibawah ini. 
Tabel 1. Analisis Matrik IFE

\begin{tabular}{c|l|c|c|c}
\hline NO & \multicolumn{1}{|c|}{ Faktor Internal } & $\begin{array}{c}\text { Bobot } \\
(\mathrm{a})\end{array}$ & $\begin{array}{c}\text { Rating } \\
(\mathrm{b})\end{array}$ & $\begin{array}{c}\text { Skor } \\
(\mathrm{axb})\end{array}$ \\
\hline & Strenght (S) & & & 0.94 \\
\hline 1. & Prosedur Perizinan cepat dan mudah & 0.22 & 4.5 & 0.63 \\
\hline 2. & Investor banyak yang percaya & 0.18 & 3.5 & 0.84 \\
\hline 3. & Sudah Mempunyai sertifikat ISO & & 4 & 0.18 \\
\hline $\begin{array}{l}\text { Weakness (W) } \\
\text { Terjadi gangguan serves pada link } \\
\text { pendaftran perijinan }\end{array}$ & 0.18 & 1 & 0.15 \\
\hline 2. & $\begin{array}{l}\text { Setiap bidang usaha mempunya ijin } \\
\text { investasi sendiri walaupun dengan } \\
\text { investor yang sama }\end{array}$ & 0.10 & 1.5 & \\
\hline 3. & $\begin{array}{l}\text { Orang di Luar Kota Depok bisa mengurus } \\
\text { ijin investasi di Kota Depok }\end{array}$ & 0.11 & 1.5 & 0.165 \\
\hline & \multicolumn{1}{l}{1.00} & & 2.955 \\
\hline
\end{tabular}

Sumber: Olahan Data Primer (2021)

Analisis Matrik EFE. Untuk melihat bagaimana analisis Standar Operasinal Prosedur (SOP) izin investasi dalam meningkatkan minat investor pada Dinas Penanaman Modal Dan Pelayanan Terpadu Satu Pintu (DPMPTSP) Kota Depok - Jawa Barat dilihat dari faktor Eksternal.Bisa dilihat ada matrik EFE dibawah ini.

Tabel 2. Analisis Matrik EFE

\begin{tabular}{c|l|c|c|c}
\hline NO & \multicolumn{1}{|c|}{ Faktor Eksternal } & $\begin{array}{c}\text { Bobot } \\
(\mathrm{a})\end{array}$ & $\begin{array}{c}\text { Rating } \\
(\mathrm{b})\end{array}$ & $\begin{array}{c}\text { Skor } \\
(\mathrm{axb})\end{array}$ \\
\hline & Opportunities (O) & & & \\
\hline $1 . \quad$ & Tempat yang strategis & 0.18 & 4 & 0.72 \\
\hline 2. & $\begin{array}{l}\text { Sebagai tempat penyangga kota-kota } \\
\text { besar disekitarnya }\end{array}$ & 0.16 & 3.5 & 0.56 \\
\hline $3 . \quad$ Pusat jasa & 0.15 & 3.5 & 0.525 \\
\hline$\quad$ Threats (T) & & & 0.66 \\
\hline 1. & Pandemi Covid 19 & 0.22 & 3 & 0.45 \\
\hline 2. & $\begin{array}{l}\text { Sudah banyah daerah lain sebagai tujuan } \\
\text { inverstasi }\end{array}$ & 0.18 & 2.5 & 0.65 \\
\hline 3. & $\begin{array}{l}\text { Investor yang melanggar akan dicabut ijin } \\
\text { investasi }\end{array}$ & 0.11 & 2.5 & 3.08 \\
\hline & \multicolumn{1}{|c}{} & 1.00 & & \\
\hline
\end{tabular}

Sumber: Olahan Data Primer (2021)

Analisis Matrik IE. Untuk melihat bagaimana analisis Standar Operasinal Prosedur (SOP) izin investasi dalam meningkatkatkan minat investor pada Dinas Penanaman Modal Dan Pelayanan Terpadu Satu Pintu (DPMPTSP) Kota Depok - Jawa Barat dilihat analisis factor internal dan eksternal.Bisa dilihat pada matrik IE dibawah ini. 
Tabel 3. Analisis Matrik IE

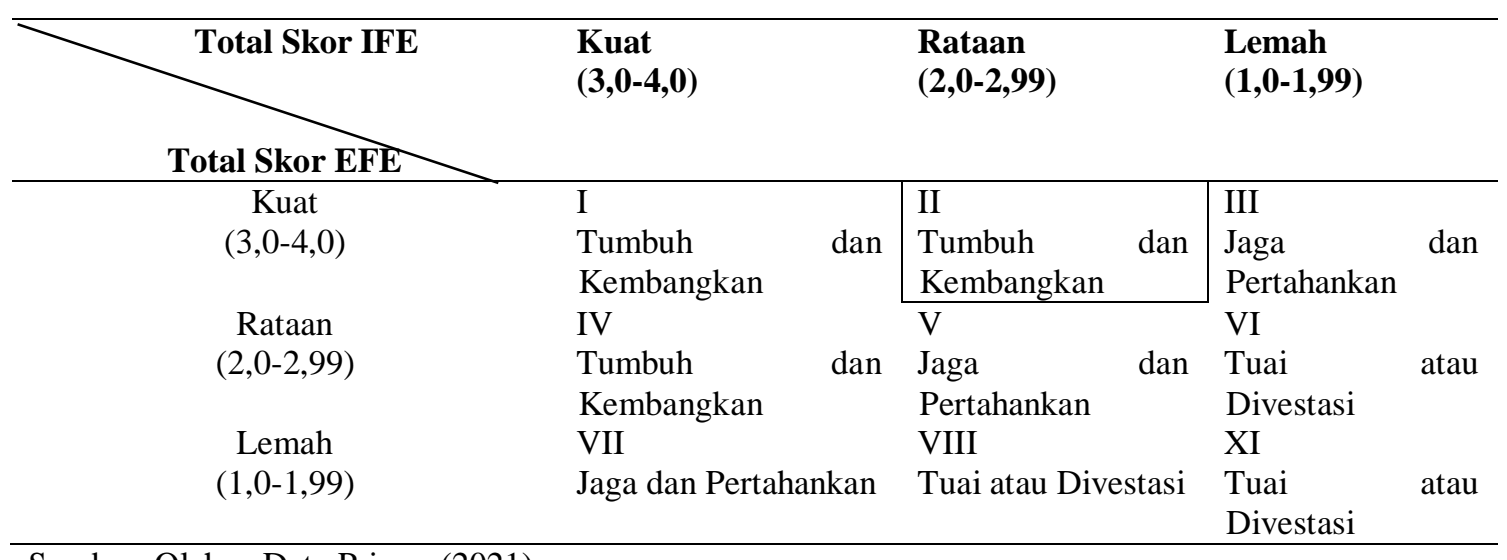

Sumber: Olahan Data Primer (2021)

Matrik internal dan eksternal disususn dari total skor matrik IFE dan EFE (2.955 dan 3.08). Hal ini dapat menunjukan bahwa posisi Standar Operasinal Prosedur (SOP) izin investasi dalam meningkatkan minat investor pada Dinas Penanaman Modal Dan Pelayanan Terpadu Satu Pintu (DPMPTSP) Kota Depok - Jawa Barat berada pada kuadran II posisis ini menunjukan bahwa Standar Operasinal Prosedur (SOP) izin investasi dalam meningkatkan minat investor pada Dinas Penanaman Modal Dan Pelayanan Terpadu Satu Pintu (DPMPTSP) Kota Depok - Jawa Barat adalah tumbuh dan kembangkan. 
Tabel 4. Analisis Analisis Swot

Opportunities (O)
Tempat yang
strategis
2. Sebagai tempat
penyangga kota-kota
besar disekitarnya
3. Pusat jasa

Threats (T)

1. Pandemi Covid 19

2. Sudah banyak daerah lain sebagai tujuan inverstasi

3. Investor yang melanggar akan dicabut ijin investasi
Strenght (S)
1. Prosedur Perizinan cepat dan mudah
2. Investor banyak yang percaya
3. Sudah Mempunyai sertifikat ISO

\section{Strategi SO}

1. Melakukuan pendekatan dengan investor yang sudah mendapatkan ijin investasi agar terus berinvestasi pada bidang usaha yang berbeda (S1,S2, O1,O3)

2. Terus menjaga kualitas SOP agar kepuasan investor tetap terjaga sehingga terus melakukan investasi $(\mathrm{S} 3, \mathrm{O} 2, \mathrm{O} 3)$

\section{Strategi ST}

1. Meningkatkan kepercayaan investor dengan terus menjalin hubungan baik dengan investor $(\mathrm{S} 2, \mathrm{~S} 3, \mathrm{~T} 2$, T3)

2. Tidak memberatkan investor terutama saat Pandemi covid 19 terkait dengan ijin usaha baru (S1, T1)

\section{Weakness (W)}

1. Terjadi gangguan serves pada link pendaftran peizinan.

2. Setiap bidang usaha mempunyai izin investasi tersendiri walaupun dengan investor yang sama.

3. Orang di Luar Kota Depok bisa mengurus ijin investasi di Kota Depok

\section{Strategi WO}

1. Menambah kapasitas server agar tidak mengalami gangguan jaringan (W1, W3, O2)

2. Memperbanyak lahan usaha untuk berinvestasi dengan mengeksplor potensi yang dimiliki Kota Depok (W3, $\mathrm{O} 1, \mathrm{O} 3)$

\section{Strategi WT}

1. Pemerintah Kota Depok melakukan webinar online untuk mempromosikan investasi di Kota Depok dengan menggandeng Kampus-kampus yang ada di wilayah Kota Depok (W2, W3, T1, T2,)

2. Memberi keringan kepada investor yang melanggar selama pelanggaran tidak berdampak besar pada Kota Depok (W1, T3)

Sumber: Olahan Data Primer (2021) 


\section{DISKUSI}

Investor yang berinvestasi di Indonesia terkait erat dengan prosedur pengelolaan izin investasi di Indonesia. Salah satunya adalah prosedur administrasi investasi. Menurut hukum dan peraturan Indonesia, prosedur manajemen ini harus diselesaikan untuk memenuhi persyaratan manajemen investor yang perlu mendapatkan izin. Investasikan untuk memulai atau menumbuhkan investasi Anda. Proses manajemen investasiInvestor harus mengikuti prosedur tertentu. Prosedur ini ditentukan oleh pemerintah sesuai dengan ketentuan yang berlaku. Hal ini untuk memastikan bahwa investasi yang dilakukan di Indonesia terdaftar dan diakui oleh pemerintah Republik Indonesia. Namun nyatanya, masih banyak investor yang belum memahami tata cara perizinan penanaman modal (SOP) saat ini, padahal izin investasi merupakan syarat hukum yang sangat penting bagi investor untuk mendapatkan pengakuan hukum atas investasinya di Indonesia.Sebelum investor dapat memulai bisnis, semua izin usaha harus diperoleh. Jika investor tidak memiliki izin investasi, maka investor tidak memiliki legitimasi, yang menyebabkan keberadaan perusahaan tidak jelas, misalnya perusahaan berbasis lahan tidak berpartisipasi dengan baik dalam sengketa tanah dan tinggal di wilayah yang tidak ada. Oleh karena itu, hal ini juga dapat mempengaruhi keberlangsungan perusahaan karena status perusahaan yang belum jelas. Dengan memberikan pelayanan perizinan yang banyak dikeluhkan masyarakat, banyak daerah atau kota yang berupaya untuk mempercepat dan mempermudah proses perizinan dengan mengembangkan unit pelayanan terintegrasi atau melimpahkan perizinan ke jalan untuk meningkatkan kualitas pelayanan. Meskipun perbaikan pelayanan telah meningkatkan kualitas, namun masih banyak permasalahan pelayanan perizinan, yaitu ketidakpastian biaya pelayanan, waktu dan prosedur pelayanan. Akibatnya, masih banyak pemerasan dan diskriminasi dalam pelayanan.Diskriminasi di sektor jasa bermula dari persahabatan, latar belakang politik dan etnis, serta masih adanya sistem demokrasi yang memeras warga negara. Melakukan Investasi adalah kegiatan ekonomi yang sangat menguntungkan. Namun perlu dipahami bahwa investor secara tidak langsung harus mempersiapkan berbagai risiko yang mungkin timbul ketika individu atau kelompok berinvestasi. Saat berinvestasi, risiko menjadi faktor yang sering dikhawatirkan semua orang, termasuk investor. Tidak ada yang suka mengambil risiko.Satu-satunya perbedaan adalah seberapa besar risiko yang dapat diambil setiap orang. Beberapa orang mengambil risiko paling kecil, tetapi sebagian dapat mengambil atau berharap mengambil risiko tertinggi.

Kota Depok - Jawa Barat sebagai kota pendukung ibu kota, tumbuh dan berkembang bersama dengan indikator kemajuan manusia. Alhasil, sarana transportasi dan infrastruktur Kota Depok semakin membaik, sehingga bisnis dan jasa Kota Depok terus berkembang. Kedekatan ibu kota menjadikan Depok sebagai kota metropolitan penyangga. DKI Jakarta. Banyak warga Depok mencari nafkah di ibu kota.Di sisi lain, Kota Depok dinilai sebagai kawasan hunian yang nyaman dan aman dengan akses yang mudah ke Jakarta. Hal tersebut menjadikan Kota Depok sebagai salah satu daerah di Indonesia yang memberikan peluang investasi yang menjanjikan bagi para investor. Selain itu, Kota Depok di Jawa Barat memiliki luas 200,29 kilometer persegi atau 0,58 ringgit. Kota Depok berbatasan langsung dengan DKI Jakarta, Tangerang Selatan, Kabupaten Bogor, dan Kota Bekasi.Letak geografis yang unik memberikan potensi investasi Kota 
Depok. Agar kegiatan investasi di Kota Depok tertib, sebelum akhirnya investor dapat berinvestasi di Indonesia, khususnya di Kota Depok, banyak prosedur perizinan yang harus dilakukan oleh instansi yang berwenang.

\section{KESIMPULAN}

Penelitian ini dilakukan untuk memberikan bukti dari Matrik internal dan eksternal disusun dari total skor matrik IFE (internal factor evaluation) dan EFE (eksternal factor evaluation) yang bernilai $(2,955$ dan 3,08$)$. Hal ini dapat menunjukan bahwa posisi Standar Operasional Prosedur (SOP) izin investasi dalam meningkatkan minat investor pada Dinas Penanaman Modal Dan Pelayanan Terpadu Satu Pintu (DPMPTSP) Kota Depok - Jawa Barat berada pada kuadrat II yaitu posisi ini menunjukan bahwa Standar Operasional Prosedur (SOP) izin investasi dalam dalam meningkatkan minat investor pada Dinas Penanaman Modal Dan Pelayanan Terpadu Satu Pintu (DPMPTSP) Kota Depok Jawa Barat adalah tumbuh dan kembangkan. Hal ini di sebabkan karena Kota Depok Jawa Barat adalah kota pemekaran yang baru berdiri sejak tahun 1999 dan laju investasi Kota Depok - Jawa Barat di mulai sejak tahun 2015 - 2018 senantiasa mengalami kenaikan tiap tahunnya dimana kenaikan dari 2015 ke 2016 mencapai 34,92\% dan dari 2016 ke 2017 mencapai 95,29 \%. Hal ini dikarenakan letak yang strategis dan berdekatan dengan Ibukota DKI Jakarta, Akses Transportasi, Infrastruktur, Demografi maupun kemudahan - kemudahan perizinan dan berinvestasi di Kota Depok - Jawa Barat menyebabkan banyak investor tertarik untuk menanamkan modalnya di Kota Depok Jawa Barat.

Dari analasis SWOT yang ada pemerintah Kota Depok - Jawa Barat harus melakukan berbagai terobosan strategi untuk meningkatkan minat berinvestasi. Langkah strategi untuk strategi SO memaparkan bahwa Pemerintah Kota Depok - Jawa Barat harus Melakukuan pendekatan dengan investor yang sudah mendapatkan izin investasi agar terus berinvestasi pada bidang usaha yang berbeda dan terus menjaga kualitas Standar Operasional Prosedur (SOP) agar kepuasan investor tetap terjaga sehingga terus melakukan investasi di Kota Depok - Jawa Barat. Strategi WO memaparkan bahwa Pemerintah kota Depok - Jawa Barat harus menambah kapasitas server pada jaringan aplikasi pembuatan izin berinvestasi dan mengeksplor potensi lokal Kota Depok - Jawa Barat agar minat investor untuk berinvestasi semakin bertambah. Strategi ST menjelaskan bahwa karena saat ini terjadi pendemi covid-19 maka ada beberapa kebijakan yang bisa diambil seperti menjalin hubungan yang baik dengan investor dan perizinan untuk usaha baru lebih dipermudah. Strategi WT menjelaskan bahwa Pemerintah Kota Depok - Jawa Barat harus melakukan kerjasama dengan kampus-kampus yang ada di wilayah Kota Depok - Jawa Barat untuk melakukan Webinar untuk membahas potensi yang dimiliki oleh Kota Depok - Jawa Barat sehingga investor bisa tau dan tertarik untuk berinvestasi dan meminimalisir biaya denda jika ada investor yang melakukan pelanggaran. 


\section{DAFTAR PUSTAKA}

Achmad Mun' im Ramadhan, M. Syaharudin, Ema Desia Prajitiasari. (2015). PengaruhPenerapan SOP (Standard Operating Procedure) dan Sistem Penghargaan (Reward System) Terhadap Kinerja Pada Karyawan Bagian Distribusi PT Unirama Duta Niaga Surabaya. Artikel Ilmiah Mahasiswa. 8(2). Hal. 7-9.

Aminudin. (2017). Peran Badan Penanaman Modal Dalam Menikatkan Pelayanan Perizinan Pariwisata Kota Batu. Jurnal Ilmu Sosial Dan Ilmu Politik. 6(2). Hal 65-68 ISSN. 2442-6962.

Atmoko, Tjipto. (2011). Standar Operasional Prosedur (SOP) dan Akuntabilitas KinerjaInstansi Pemerintah. Unpad, Bandung.

Bakhri Syaeful. (2014). Minat Mahasiswa Dalam Investasi Di Pasar Modal. Al-Amwal, $10(1)$.

Bustami. (2011). Penjamin Mutu Pelayanan Kesehatan dan Akseptabilitasnya. Erlangga, Jakarta.

Dita, Made Ambara dan I Wayan Putra. (2016). Pengaruh Penerapan Sistem InformasiAkuntansi Terhadap Kinerja Karyawan Dengan Integritas Karyawan sebagai Variabel Pemoderasi. E-Jurnal Akuntansi Universitas Udayana. 15(1), ISSN 2302-8556.

Gabriele. (2018). Analisis Penerapan Standar Operasional Prosedur (Sop) Di Departemen Marketing dan Hrd Pt Cahaya Indo Persada . AGORA, 6( 1).

Gunawan Hendra, Hakim Budiman Dedi dan Hariyoga Himawan. 2020. Strategi pelayanan perizinan untuk meningkatkan investasi di kabupaten bogor. Jurnal Manajemen Agribisnis : 8.(1).doi: https://doi.org/10.24843/JMA.2020.v08.i01.p08.

Hartono, Jugiyanto. (2015). Teori Portofolio dan Analisis Investasi. Edisi Kelima. Jakarta: Rajawali Pers.

Hati Wahyu Shinta dan Harefa Septiani Windy. (2019). Analisis faktor-faktor yang mempengaruhi minat berinvestasi di pasar modal bagi generasi milenial. Jurnal of business administration. 3(2). doi: https://doi.org/10.30871/jaba.v3i2.1529.

Khairani, M. (2017). Psikologi Belajar. Yogyakarta: Aswaja Pressindo.

Lubis, Adyanata. (2016). Basis Data Dasar Untuk Mahasiswa Ilmu Komputer. Yogyakarta: CV. Budi Utama.

Martalena, dan Malinda. (2011). Pengantar Pasar Modal. Edisi Pertama. Yogyakarta : Andi.

Malik, A. D. (2017). Analisa Faktor - faktor Yang Mempengaruhi Minat Masyarakat Berinvestasi di Pasar Modal Syariah Melalui Bursa Galeri Investasi UISI. Jurnal Ekonomi dan Bisnis Islam, Vol. 3, No. 1, 61 - 84.

Moleong, Lexy. J. (2016). Metodologi Penelitian Kualitatif Edisi Revisi. Bandung: PT. Remaja Rosdakarya.

Nurlita Anna. (2014). Investasi di Pasar Modal Syariah dalam Kajian Islam, Jurnal Penelitian Sosial Keagamaan. 17(1).

Peristiwo Hadi. (2016). Analisis minat investor di kota serang terhadap investasi syariah pada pasar modal syariah. Jurnal ekonomi keuangan dan bisnis islam . 7(1). Hal 3752 . 
Rai Widjaya. (2015). Penanaman Modal: Pedoman Prosedur Mendirikan dan MenjalankanPerusahaan Dalam Rangka PMA dan PMDN, Jakarta: PT Pradnya Paramita.

Rachmi Annisa, Susanto Dwi Tony dan Herdiyanti Anisah. (2014). Pembuatan Standard Operating Procedure (SOP) Service Desk Berdasarkan Kerangka Kerja Itil V3 dengan Menggunakan Metode Analisis Gap Layanan (Studi Kasus: PT. XYZ , Tangerang). JURNAL TEKNIK POMITS Vol. 3, No. 2, (2014) ISSN: 2337-3539 (2301-9271 Print).

Setiawati, Wiwien. (2015). Penyususnan Standard Operating Prosedur (SOP) Pada PT Sketsa Cipta Graha di Surabaya. Agora Vol.3, No.1. http://studentjournal.petra.ac.id/index.php/manajemen-bisnis/article/view/2906.

Slameto. (2010). Belajar dan faktor-faktor yang Mempengaruhinya. Jakarta: PT. RinekaCipta.

Sriasih Putu Ni. I dan Wahyuni Arie Made. (2020). Determinan Minat Berinvestasi Mahasiswa di Pasar Modal. Ekuitas: Jurnal Pendidikan Ekonomi .8(2), pp. 190-195

Suparji. (2010). Pengaturan Penanaman Modal di Indonesia, Universitas Alazhar Indonesia, Jakarta.

Syahyunan. (2015). Manajemen Keuangan 1, Edisi ketiga, USU press, Me Dan.

Syahyunan. (2015). Manajemen Keuangan: Perencanaan, Analisis, dan PengendalianKeuangan (Edisi kedua). Medan: USUpress.

Tandio, Timothius dan Widanaputra, A.A.G.P. (2016). Pengaruh Pelatihan Pasar Modal, Return, Persepsi Risiko, Gender, dan Kemajuan Teknologi pada Minat Investasi mahasiswa. E-Jurnal Akuntansi Universitas Udayana Vol. 16.3 (ISSN : 2302-8556).

Tumewu J. Ferdinand. (2019). Minat investor muda untuk berinvestasi di pasar modal melalui teknologi fintech. Jurnal ilmial manajemen bisnis dan inovasi. 6(2) hal. 133146.

Widyastuti Budhi. (2014). Analisis Kualitas Pelayanan Perizinan Investasi di UPT Pelayanan Perizinan Terpadu (P2T) Provinsi dalam Meningkatkan Investasi di Jawa Timur . Kebijakan dan Manajemen Publik, 1(1). ISSN 2303 - 341X. 